\title{
Implant Dosing Unit
}

National Cancer Institute

\section{Source}

National Cancer Institute. Implant Dosing Unit. NCI Thesaurus. Code C48499.

A dosing unit equal to the amount of active ing redient(s) contained in an implant. 